\title{
Stakeholder perception of EU food safety governance: the case of EU fruit and vegetable imports from Southern Mediterranean Countries
}

\author{
luca Camanzi ${ }^{*}$, Abdelhakim Hammoudi**, Giulio Malorgio*
}

DOI: $10.30682 / \mathrm{nm} 1904 \mathrm{~b}$

JEL codes: Q13, Q17, Q18

\begin{abstract}
Despite the advantages ensuing from preferential market access agreements, trade exchanges between Southern Mediterranean Countries (SMCs) and the EU are often hindered by food safety issues. These are particularly relevant for fruit and vegetables, which are subject to heterogeneous regulations in SMCs.

This paper seeks to outline governance solutions to improve ex-ante compliance capacity of SMCs production and to enhance integration with the EU market. A set of research hypotheses, concerning the difficulties and benefits related with food safety compliance, are formulated. These hypotheses are then discussed in the light of the empirical evidence gathered from (i) public bodies involved in food safety enforcement and (ii) a direct survey conducted on 37 stakeholders in the fruit and vegetable supply chain in Italy.

The main problems identified relate to the scarce harmonization among control systems in EU Member States and insufficient checks in exporting countries. The main benefits include the reduction of sanitary risk and the reinforcement of long-term trust-based relations along the supply chain. The most promising strategies encompass the improvement of inspections on production sites and of infrastructures in the countries of origin. Further areas of intervention concern the harmonization of food safety regulation between EU countries and SMCs and the development of bilateral cooperation and technical training programs.
\end{abstract}

Keywords: Fruit and Vegetables, International Trade, Food Safety Regulation, Southern Mediterranean Countries, Delphi method, Maximum Residue Limits, Stakeholders, Co-regulation.

\section{Introduction}

Compliance with mandatory Sanitary and Phytosanitary Standards and food safety requirements are crucial issues for international trade (Otsuki et al., 2001; Wilson, 2000). Food import safety constitutes an important subject in the EU food safety legislation that aims at ensuring that all the merchandises entering the EU market comply with the same regulations imposed to European producers (Regulation (EC) No 178/2002, Regulation (EC) 396/2005 and Regulation (EC) No 178/2006). EU regulations are currently considered as the most severe at international level, as compared, for example, to the Codex Alimentarius. However, the complexity

\footnotetext{
* Department of Agricultural and Food Sciences, University of Bologna, Italy.

** INRA, ALISS, Paris, France.

Corresponding author: luca.camanzi@unibo.it
} 
of import procedures, the large number of public bodies involved and the risk of failure (liability and market sanctions) can have a negative impact on domestic players downstream the supply chain, entailing a heavy administrative burden and additional costs.

A further controversial issue concerns the implementation of food standards and control systems by each Member State (Whitakert et al., 1995; Willems et al., 2005), that, along with the complexity of administrative import procedures, may favor opportunistic behavior to the detriment of both consumer health and supply chain transactions efficiency (Grazia et al., 2015). In fact, EU food safety legislation most often regulates "results" (e.g. maximum admitted levels of contaminants) without specifying what means/ inputs should be used to achieve these results.

These are issues of high relevance especially with regard to trade flows between countries characterized by heterogeneous agricultural production conditions and regulations. It is particularly the case of for fresh fruit and vegetables (FVs) imported by EU Member States from Southern Mediterranean Countries (SMCs). In fact, trade flows of agricultural and food products between EU Member States and SMCs has intensified significantly in the last decades and particularly imports of France, Italy, Spain and Greece from Algeria, Egypt, Morocco and Turkey (Crescimanno et al., 2013). Furthermore, Malorgio and Grazia (2013) pointed out that FVs imported by Italy from SMCs may be considered not only substitutes for domestic products, but in many cases they are complements for the product range required to meet the national and EU market demand.

However, despite the advantages deriving from preferential access conditions, granted by the European Union to the southern Mediterranean countries, ample difficulties still persist in the organization and expansion of the export flows of these countries towards the EU market.

The aim of this paper is to evaluate the current EU food safety governance and public regulatory action, with a special focus on fruit and vegetable imports from SMCs. Specifically, the study aims has the following three specific objectives: (i) to evaluate the current enforcement capacity of EU food safety regulation among EU Member States, as well as the degree of harmonization of the legislation with SMCs; (ii) to highlight the impacts of the EU inspection system organization on supply chain relationships and (iii) to provide recommendations on suitable policy intervention tools favoring compliance with food safety requirements and support the development of South-North Mediterranean trade flows.

The research focuses on the implications entailed by the current EU food safety regulation on Italian firms importing fresh fruit and vegetables from Southern Mediterranean Countries. Its specific objectives are to identify the main benefits and difficulties of compliance with food safety regulation perceived by domestic operators and to provide recommendations on suitable policy intervention tools.

The study was developed in three steps. First, we conducted an overall assessment of the compliance capacity of fruit and vegetables imported from SMCs, by means of secondary data gathered from the European Food Safety Authority and the Italian Ministry of Health. Secondly, we formulated a set of research hypotheses on the main factors affecting compliance capacity according to the relevant scientific literature. Thirdly, based on these hypotheses, we carried out a direct survey in Italy on 37 key players involved in fruit and vegetable imports from SMCs, concerning their perception of the food safety governance, compliance process and needs for improvement.

\section{International food safety regulation and governance}

The growing awareness of the role of food quality and health has led to the emergence of national and international regulations, which have profoundly changed production practices and the organization of supply chains.

On a global level, three organizations with complementary missions are involved in the definition of domestic market food safety means: the Food and Agriculture Organization (FAO), the World Health Organization (WHO) and World 
Organisation for Animal Health (OIE). Following a Joint FAO / WHO Food Standards Programme, the Codex Alimentarius Commission ("Codex" or "Food Code"), develops international standards for food products and provides a framework for stakeholders at various stages of the food supply chain to minimize the risk of contamination and the final product toxicity. The Codex Commission develops international standards, guidelines and recommendations to support the development of national regulations in the field of food safety and food quality. The Food Code includes standards for all principal foods, whether processed, semi-processed or raw, for distribution to the consumer. In addition, the Codex evaluates pesticides, food additives and veterinary drugs and establishes limits for pesticide residues and guidelines for contaminants. Furthermore, the International Organization for Standardization (ISO) establishes international standards that are essentially voluntary nature on a range of products, services and management systems.

As far as multilateral trade is concerned, food safety issues are regulated by the World Trade Organization (WTO) Agreement on Sanitary and Phytosanitary Measures (SPS), aiming to (WTO, 2015):

a) protect animal or plant life or health within the territory of the Member from risks arising from the entry, establishment or spread of pests, diseases, disease-carrying organisms or disease-causing organisms;

b) protect human or animal life or health within the territory of the Member from risks arising from additives, contaminants, toxins or disease-causing organisms in foods, beverages or feedstuffs;

c) protect human life or health within the territory of the Member from risks arising from diseases carried by animals, plants or products thereof, or from the entry, establishment or spread of pests; or

d) prevent or limit other damage within the territory of the Member from the entry, establishment or spread of pests (WTO, 2015).

At regional level, the EU has developed comprehensive legislation and extended to en- sure that food provided to consumers through this vast and complex food system is safe and healthy. The basic principles of the food law in EU are set out in Commission Regulation (EC) No 178/2002, establishing that the primary responsibility for food safety lies with companies that are located throughout the food production chain. As part of the Hygiene Package, Regulation (EC) No 852/2004 lays down general rules for food business operators on food hygiene and applies to every stage of production, processing and distribution of food. This regulation is based on the following principles: (a) primary responsibility for food safety to food business operators; (b) chain approach (ensuring safety throughout the chain from primary production, maintenance of the cold chain; (c) implementation of procedures based on HACCP principles (Article 5); (d) application of good hygiene practices.

\subsection{Maximum limits for contaminants}

As far as international trade of fruit and vegetables is concerned, the presence of contaminants is an issue of great importance to ensure both appropriate safety standards for consumers and fair competition for supply chain actors. This is why EU regulation on maximum harmful substances has progressively strengthened the conditions of access to the EU market (see for instance Regulation No 466/2001 and Regulation No 1881/2006).

Downstream the supply chain, a reference device regulates the maximum amount of pesticides allowed for certain products, i.e. the Maximum Residue Levels (MRLs). The EU MRL harmonization program has led to the development of common and mandatory limits for active ingredients registered by the EU (Regulation (EC) No 396/2005 on maximum residue levels of pesticides in or on food and feed of plant and animal origin). The approval of the active substances is one of the essential elements of the system: it provides for the periodic review of the list of approved substances, leading to the maintenance or the release of the list of a number of pesticides. The entry or exit of pesticides from the European list depends on scientific knowl- 
edge on the toxicity of the substances used, but also, to some extent, on innovation activities and the information provided by agrochemical companies. When active substances are removed from this list, their MRL detection threshold is set to zero. Any such measure may however be canceled if exporters from third countries provide scientific proof of import tolerances of the active substances. The European Union has embarked on the harmonization of the applicable maximum limits program. The new regulatory framework is applied from 1 September 2008 and provides for harmonized European MRLs (national MRLs lists are deleted). The establishment of the EU list entails stricter provisions than some previous provisions. Thus, the harmonization procedure ensures a greater degree of protection of the health of the European consumer while ensuring a better functioning of trade (Coutrelis, 2009).

\subsection{Official controls on import goods: sam- ples and analysis}

In order to monitor and verify that operators comply with the requirements of EU legislation on food safety and animal feed, Member States are required to implement a system of controls. The regulatory framework of official controls at European level is based on Regulation (EC) No $882 / 2004$ that sets out a harmonized set of general rules for official controls to be performed, including those made during the introduction of food and feed from third countries. Furthermore, Regulation (EC) 669/2009, sets out the minimum requirements for border inspection post through which imports can enter the EU market. These requirements include:

a) suitably qualified and experienced staff in sufficient number to perform the prescribed checks on consignments;

b) adequate facilities for the competent authority to undertake the necessary checks;

c) detailed instructions regarding sampling and dispatch of samples for analysis by a laboratory designated in accordance with Article 12, paragraph 1 of Regulation (EC) No 882/2004; d) facilities to store consignments in appropriate conditions during the period of detention, where appropriate, pending the results of the analysis referred to in c) and a number of sufficient conservation rooms, cold rooms, where a controlled temperature is required due to the nature of the consignment;

e) unloading equipment and appropriate equipment for carrying out sampling for analysis;

f) the possibility to perform the unloading and the sampling for analysis in a sheltered spot, if necessary;

g) a designated laboratory which can perform the analysis referred to in c) and is located in a place to which it is possible to rapidly transport the samples.

Beyond the minimum requirements of entry points, there is heterogeneity in endowments that can induce performance heterogeneity of the various border checkpoints. This diversity is reflected among other things in a different staffing, infrastructure, in batches storage facilities, in storage rooms, in appropriate equipment for carrying out sampling and analysis, laboratory, etc.

\section{Theoretical background and research hy- potheses}

Public intervention in the area of food safety and quality is justified by information asymmetries between the phase of production and consumption, by externalities associated with the consumption of food and by the need to guarantee the protection of minimal requirements in terms of consumer health, market information and commercial loyalty along the supply chain.

The international food safety regulation, particularly in the EU, consists of a dosage of devices operating upstream and downstream the supply chain aimed at correcting market inefficiencies and at pursuing the achievement of the socially optimal level of quality.

Upstream devices act at different stages of the supply chain, defining the production and processing practices constituting the reference 
requirements for operators. Downstream devices consist, in general, of standards that set the maximum thresholds for residues of harmful substances that can be tolerated in a final product destined for feeding.

However, technical measures (regulation of food safety, quality standards, labeling requirements, etc.) can act as a barrier to trade as much as tariffs and quantitative restrictions (Laird and Yeats, 1990; Vogel, 1995). In fact, EU tariff quotas and import calendars are flanked by (i) strict non-tariff rules, such as those provided for in the fruit and vegetable CMO, relating to quality, labeling and marketing and (ii) phytosanitary standards, aimed at protecting the health of the consumer and the environment, all factors that reduce the export capacity of these countries to the Community market. In the particular case of agri-food exports, compliance with technical requirements is a pre-requisite for export (Horton, 1998). As illustrated by Henson and Loader (2000) - who analyzed the major obstacles to exporting agricultural products to the EU market - SPS measures are the main obstacle, followed by technical requirements, tariffs and quantitative restrictions.

In general, compliance with food safety standards (whether obligations of means or obligations of results) entails capital investments (e.g. manufacturing plants, structures for the implementation of procedures and control tests) as well as additional variable costs (e.g. labour). Fixed costs affect the profitability of companies and variable costs can considerably reduce the volume of exports (Emlinger et al., 2008).

The evolution of the regulation concerning the maximum levels of contaminants and the methods of control, sampling and analysis adopted in the countries of destination influences, in the long run, the rejection rate of imported goods. However, traditional command-and-control regulation by public authorities is increasingly replaced, both in political theory and in practice, by alternative, flexible, less state-centered forms of regulation, such as self-regulation, co-regulation, management-based regulation and private systems of governance (Aalders et al., 1997, Havinga, 2006; Malorgio et al., 2016; Garcìa Martinez and Poole, 2004). In fact, regulatory action often demonstrates rather high rates of non-compliance, as coercion can breed minimalist approaches to compliance resulting in sub-optimal improvements to public health alongside significant expenditure of resources on enforcement and monitoring (Garcìa Martinez et al., 2007). On the contrary, a co-regulation approach would set up dedicated structures and implement procedures by means of joint resources (equipment, staffing, etc.) and "task sharing", with potentially relevant benefits on food safety (Fares and Rouviere, 2010).

Research conducted on this issue often emphasizes the role of the sampling and analysis methods in differences in judgments on the same product from the same origin. Even if the trend is to harmonize procedures, there are still significant differences at this level particularly in terms of procedures and sample rates, human resources allocated to ports of entry, the technical capacity to detection (Fakhfakh et al., 2009; Willems et al., 2005).

In light of the above, we formulate the following research hypotheses.

H1: Compliance with food safety standards reduces health risk and commercial risk associated with market failures, thus improving market access capability. However, harmonization issues still exist between EU and Southern Mediterranean Countries regulation, as well as among EU Member States implementation (Giraud-Héraud et al., 2012; Ait Hou et al., 2015).

H2: Ex-ante compliance with food safety requirements can be improved by effective inspection/control procedures. In this respect, obligations of means may be more effective than obligations of results (Grazia et al., 2012).

H3: Compliance difficulties can be related to the nature of information and the complexity of vertical relationships along the food supply chain (i.e. difficulties in monitoring/selecting suppliers) (Starbird and Amanor-Boadu, 2007; Starbird, 2005). 
Furthermore, the complexity of vertical relationships along the food chain may affect compliance capacity (Grazia and Hammoudi, 2012).

H4: Private standards may act as complements to public regulations as a tool of upstream "regulation", favoring ex-ante compliance capacity (Hamza et al., 2014; Fares and Rouviere, 2010). Furthermore, food safety governance could be enhanced introducing a co-regulation approach, entailing that public and private sectors work hand in hand to deliver safer food safety at lower cost (Garcia Martinez et al., 2007).

\section{Data and methods}

As a first step of the study, an empirical analysis assessing the importance of the border rejection phenomenon and its evolution over the time has been conducted. The study compares the fruit and vegetable imports of Italy, Spain and France from Morocco, Egypt, Algeria, Tunisia and Turkey, over the period 2009-2015. The analysis aims at evaluating SMCs possibilities to meet EU food safety standards in the context of trade flows and to highlight the level of control system and harmonization among the EU countries. The analysis is based on the data provided by the European Commission Rapid Alert System for Food and Feed (RASFF) and include for each rejected consignment the county of origin, the product involved and the hazard category or risk source, over the period 2009-2015. The products considered were fresh and dried fruit and vegetables (except edible nuts and groundnuts).

As a second step of the study, the research hypotheses formulated in section 3, were used to frame a direct survey on key players involved in food safety and trade in the Italian FV sector. The expert panel was composed of $37 \mathrm{key}$ players and representatives from national and regional authorities international transport/logistic providers, exporters' associations, producer organizations and trade consultants. Through in-depth interviewing we gathered their opinion on the structure and functioning of the current import safety regulation system. To do that, we adopted a Delphi approach that allows to achieve an informed judgment by collecting and refining information based on the knowledge of a group of experts (panel), through a series of questionnaires and feedback on the opinions expressed. The method includes a multistage process involving the initial measurement of opinions (first stage), followed by data analysis, design of a new questionnaire, and a second measurement of opinions (second stage). Among the various Delphi implementation methods available, we choose a "mini Delphi" method (Helmer, 1972), entailing semi-structured interviews in the first stage and an informal consultation in the second stage. The main topics targeted by the interviews include the expected benefits arising from compliance with health standards currently in force, as well as the main difficulties in ensuring the health security in the FV imports, but also strategies and tools that could be implemented to facilitate compliance with health standards. The questionnaire included both open-ended questions and closed-ended questions. Most of these where assessed with a five-point Likert scale to gather attitudinal or preferential data from respondents. The following informal consultation has been conducted with no strict scaling of responses, but with the aim to provide a shared vision of the most appropriate policy orientation and lines of action that should be taken.

\section{Results}

\subsection{EU food safety regulation governance and implementation assessment}

As a preliminary result, we provided an assessment of the food safety regulation and its implementation system, both at the EU level and at Member State level, with specific reference to Italy.

According to Regulation (EC) No 882/2004, official controls include at least a systematic documentary check, a survey by identity check and, if necessary, a physical check. 
As far as the administrative documents are concerned, the general regulation for food and grocery requires that both a certificate of Pan-Euro-Mediterranean origin is provided and that the transport documentation is issued by the customs offices. Further specific documents required for FV produce are the Phytosanitary Certificate, the Sanitary Certificate and the Quality Certificate.

In the downstream supply chain, liability rules are designed to sanction non-compliant behaviors (Polinsky and Shavell, 2006; Hobbs, 2006; Rouvière and Latouche, 2014). In fact, products not complying with the food safety standards that may be detected are either returned to the country of origin, transferred to another country ready to accept the provision or destroyed within the importing country, entailing market sanctions and important consequences in terms of both country and individual firm reputation. In case of non-compliance with labeling information, products can be downgraded to a lower quality category or, in case the product does not fit into any lower quality category, they will be either returned to the country of origin, sent to a third country, or destroyed.

\subsubsection{Import rejections per country of origin}

According to EFSA (European Food Safety Authority, 2015), in 2014 the official control activities performed by EU Member States to ensure compliance of food with the legal limits for pesticide residues (MRLs) concerned 80,967 samples for a total of 685 different pesticides. On average, samples were analyzed for 200 pesticides. $68.2 \%$ samples are originated from the EU and Europe Economic Area (EEA) countries, and 27,7\% concerned products imported from third countries. When compared with samples from the EU and EEA countries, those from third countries were found to have a higher MRL exceedance rate $(5.7 \%$ vs $1.4 \%)$ and non-compliance rate $(3.4 \%$ vs $0.7 \%)$. In most cases these MRL exceedances for pesticides not approved in the EU were related to imported products $(23.6 \%$ vs $6.7 \%$ ). However, compared to 2012 the MRL exceedance rate for imported food products declined $(7.5 \%)$.

Among the 2,788 individual determinations that exceeded the legal limit, 878 were reported for pesticides not approved in EU. In most cases the MLR exceedances for non-approved pesticides were related to import products (659 cases).

The highest rates of samples analyzed of imported products from third countries are registered in Bulgaria (92.8\%), Netherlands (65.1\%) and, to some extent, in France (31.7\%). On the contrary, in Spain and Italy the rates of sample analyzed are respectively of $10.1 \%$ and $9.4 \%$, quite below the EU average (28.2\%).

However, the distribution of FV import rejections is quite different among the three EU countries considered (Table 1). In Italy rejections are regularly distributed among the export countries with a higher number for Turkey. In France rejection are concentered exclusively on Turkey and absent for other countries, while in Spain the rejections are notified for two countries: Turkey and Morocco.

\subsubsection{Import rejections per product category}

The products with the highest MRL exceedance rate are strawberries $(2.5 \%$ of the samples $)$, lettuce $(2.3 \%)$, peaches $(1.1 \%)$ and tomatoes $(0.9 \%)$, but these are most often produced in EU and EEA countries (Iceland, Estonia, Bulgaria and Cyprus) and Third Countries (China) rather than SMCs. Actually the only relevant MRL exceedance rate detected among SMCs relates to tomatoes produced in Morocco $(2.4 \%)$, but it is still very close to those observed for tomatoes produced in Poland $(2.5 \%)$, Greece $(2.3 \%)$ and Italy $(2.1 \%)$ and much lower than that of Portugal $(4.2 \%)$.

The products with the highest number of rejections are dried figs imported from Turkey both by France and Italy (Table 2). In Spain there are various notifications for different products from Morocco and a high number for dried figs and apricots from Turkey. 
Table 1 - Rejections of fruit and vegetable imports per Country of Origin.

\begin{tabular}{|c|c|c|c|c|c|c|c|c|}
\hline $\begin{array}{l}\text { Importing } \\
\text { Country }\end{array}$ & $\begin{array}{l}\text { Country } \\
\text { of Origin }\end{array}$ & 2009 & 2010 & 2011 & 2012 & 2013 & 2014 & 2015 \\
\hline \multirow{7}{*}{ Italy } & Egypt & & 3 & 5 & 7 & 2 & 3 & 9 \\
\hline & Morocco & & & 1 & & 1 & 1 & \\
\hline & Tunisia & 1 & & 1 & & 2 & 5 & 6 \\
\hline & Turkey & 9 & 1 & 8 & 19 & 21 & 4 & 7 \\
\hline & Algeria & 1 & & & & & & \\
\hline & Egypt & & & & & & 4 & 1 \\
\hline & Morocco & & & & & & & \\
\hline \multirow{5}{*}{ France } & Tunisia & & & & & & & \\
\hline & Turkey & 25 & 27 & 7 & 18 & 62 & 14 & 15 \\
\hline & Algeria & & & & & & & \\
\hline & Egypt & & & & & & 1 & \\
\hline & Morocco & & 2 & 3 & 3 & 1 & 1 & \\
\hline \multirow{3}{*}{ Spain } & Tunisia & & & & & & & \\
\hline & Turkey & 1 & 3 & & & 4 & 3 & 9 \\
\hline & Algeria & & & & & & & \\
\hline
\end{tabular}

Source: authors' elaboration on RASFF data.

Table 2 - Rejection of fruit and vegetable import per country of origin and per product (2009-2015).

\begin{tabular}{|c|c|c|c|c|c|}
\hline $\begin{array}{l}\text { Importing } \\
\text { Country }\end{array}$ & $\begin{array}{l}\text { Country } \\
\text { of origin }\end{array}$ & $\begin{array}{l}\text { Product } \\
\text { categories }\end{array}$ & $\begin{array}{l}\text { Border rejection } \\
\text { notifications (n.) }\end{array}$ & $\begin{array}{c}\text { Risk sources per \% of } \\
\text { border rejection notification }\end{array}$ & $\begin{array}{c}\text { Rejections per } \\
\text { imports (n/,000ton) }\end{array}$ \\
\hline \multirow{17}{*}{ Italy } & \multirow{8}{*}{ Egypt } & Strawberry & 6 & Pesticides & 39.67 \\
\hline & & Pomegranate & 1 & Pesticides & n.a. \\
\hline & & Onion & 2 & Pesticides & 0.35 \\
\hline & & Beans & 11 & Pesticides & 0.20 \\
\hline & & Pepper & 2 & Pesticides & 13.01 \\
\hline & & Tomato dried & 1 & Moulds & 2.39 \\
\hline & & Artichokes & 2 & Pesticides & na \\
\hline & & Orange & 2 & Pesticides & 0.21 \\
\hline & \multirow{3}{*}{ Morocco } & Clementines & 1 & Pesticides & na \\
\hline & & Strawberries & 1 & Pesticides & 0.73 \\
\hline & & Olives & 1 & Pesticides & na \\
\hline & \multirow{6}{*}{ Tunisia } & Chili pepper & 1 & Absence of certificate & 250 \\
\hline & & Artichokes & 1 & Pesticides & na \\
\hline & & Dates & 6 & Died insect & 0.48 \\
\hline & & Oranges bitter & 1 & Moulds & 400 \\
\hline & & Melons & 1 & Pesticides & 2.76 \\
\hline & & Strawberries & 1 & Bad state of preservation & 500 \\
\hline
\end{tabular}




\begin{tabular}{|c|c|c|c|c|c|}
\hline \multirow{6}{*}{ Italy } & \multirow{5}{*}{ Turkey } & Cherries & 5 & Pesticides & 1.74 \\
\hline & & Dried figs & 49 & Micotoxine & 3.03 \\
\hline & & Pomegranates & 1 & Pesticides & na \\
\hline & & Apricot dried & 2 & Sulphite & 1.09 \\
\hline & & Dried raisin & 2 & Micotoxine/Sulphite & 0.06 \\
\hline & Algeria & Onion & 1 & Bad state & 1.09 \\
\hline \multirow{4}{*}{ France } & \multirow{2}{*}{ Egypt } & Strawberry & 3 & Pesticides & 1.6 \\
\hline & & Pepper & 1 & Pesticides & 714.2 \\
\hline & \multirow[t]{2}{*}{ Turkey } & Dried figs & 153 & $\begin{array}{c}\text { Micotoxine }(96 \%) \\
\text { Absence of certificate }(4 \%)\end{array}$ & 2.02 \\
\hline & & Dried Apricots & 1 & Sulphite & 0.69 \\
\hline \multirow{11}{*}{ Spain } & Egypt & Raisin & 1 & Damaged packaging & na \\
\hline & \multirow{8}{*}{ Morocco } & Courgettes & 2 & Pesticides & 0.27 \\
\hline & & Melons & 1 & Mould & 0.19 \\
\hline & & $\begin{array}{l}\text { Raspeberries } \\
\text { and bilberries }\end{array}$ & 1 & Damaged packaging & 27.17 \\
\hline & & Pumpkin & 1 & Spoilage & na \\
\hline & & Pepper & 1 & Bad state & 0.33 \\
\hline & & Potatoes & 1 & Moulds & na \\
\hline & & Beans & 2 & Moulds & 0.02 \\
\hline & & Olives & 1 & Pesticides & na \\
\hline & \multirow{2}{*}{ Turkey } & Dried figs & 10 & Micotoxine & 1.51 \\
\hline & & Dried Apricots & 10 & Sulphite & 1.55 \\
\hline
\end{tabular}

Source: authors' elaboration on RASFF data.

\subsubsection{Heterogeneity in EU entry point inspections}

Based on the information presented, we can argue that fresh FVs imported by EU Member States from SMCs generally meet the food safety requirements imposed by the EU legislation. However, the same evidence suggests that control systems at both European and national level are heterogenous.

Beyond the minimum requirements required for designated entry points, there is heterogeneity in the means and endowments in terms of personnel, infrastructure, facilities to store lots, storage rooms, unloading equipment and appropriate equipment for carrying out sampling for analysis, the presence of a designated laboratory which can perform the analysis, etc.
Indeed, the EFSA itself acknowledges that limited capacities and resources are available for pesticide residue analysis in the competent national food authorities and that a proper planning of the national and EU-wide monitoring programs is necessary to enable better targeting of resources (European Food Safety Authority, 2015).

The heterogeneity of control systems (at EU or national level), can determine the strategic behavior by importers in selecting the entry point. Thus, beyond the products covered by the reinforced controls, choosing the point of entry by the importer that fact on the basis of strategic considerations. This particular choice is clear from the consideration of costs (transportation costs, cost control, cost-opportunity, tariffs) and benefits (speed controls and efficiency). 
The frequency of physical checks is another critical issue, being determined by a number of factors. These include: (i) the risks associated with different types of feed and food, (ii) the historical record of non-compliance by the exporting country or operators importing the product. Hence, while enhanced controls with more frequent physical checks are set out for certain product categories originating from specific third countries.

In the case of Italy, for example, for products that are not covered by the reinforced controls described above, the presidential decree of 14 July 1995 defines a frequency of 5\% of the incoming batches. If there are special reasons, such as in case of suspicion, this frequency can be $100 \%$. In the case of MRL (pesticides) frequency is set at $3 \%$ by a decree of the Ministry of Health of 30 July 1993. In the case of the UK, the frequency is set by the port authorities. In Greece, the percentage can vary from $5 \%$ to $100 \%$ depending on the product and country of origin. In Finland, the sampling rules are established by customs. In Hungary, no sampling rule was in force before June 2007, except for the case of pesticides in fruits and vegetables.

In addition, laboratory accreditation to ISO standards is not widespread and some laboratories are not accredited. In addition, an audit entry points system according to ISO 19011 (standard providing guidelines for auditing management systems) is not always implemented. This results in significant differences in judgments about the conformity of lots submitted for inspection.
The analysis of regulations and measures actually implemented at entry points shows that control procedures have relevant gaps and that they are not always effectively carried out. Such gaps are officially recognized by the EU authorities responsible for the issue of the safety of imports. The European action memorandum on the safety of imports in the Union presented at the Council of Agriculture Ministers of 23 June 2008 explicitly points to these issues. The report finds that «the weaknesses are particularly related to differences in practice between Member States on the implementation of controls», in the absence of a genuine risk analysis to identify the most problematic products, and an incomplete harmonization of rules.

\subsubsection{Differences between EU and SMCS regulations}

Further evidence of the lack of harmonization emerges from the analysis of the list of active substances approved in different countries. As an example, we hereby provide a comparison of the number of active substances and LMR approved in EU and Morocco for two products: citrus and tomato (Table 3 ). We observe that $18 \%$ of MRLs allowed for tomato in Morocco are greater than those allowed in the EU, while $62 \% \mathrm{t}$ of the EU MRLs are the same or greater than those of Morocco. In the case of citrus imports coming from Morocco $17 \%$ of them is greater than the EU MRLs, while $62 \%$ of the EU MRLs are the same or greater than the Morocco MRLs.

Table 3 - Differences between MRLs for tomato and citrus in EU and Morocco regulations.

\begin{tabular}{|l|c|c|c|c|}
\hline \multirow{2}{*}{ Number of substances for which... } & \multicolumn{2}{|c|}{ Citrus } & \multicolumn{2}{c|}{ Tomato } \\
\cline { 2 - 5 } & $E U$ & Morocco & $E U$ & Morocco \\
\hline there are MRLs assigned & 434 & 69 & 459 & 108 \\
\hline there is an EU MRL but no Morocco MRL & 367 & & 353 & \\
\hline there is a Morocco MRL but no EU MRL & & 12 & & 6 \\
\hline the EU MRL is greater than the Morocco MRL & 2 & & 16 & \\
\hline the Morocco MRL is greater than the EU MRL & & 12 & & 19 \\
\hline EU and Morocco MRLs are the same & 43 & & 67 & \\
\hline
\end{tabular}

Source: authors' elaboration on various sources (ONSSA Morocco, EU DG Health and Food Safety). 


\subsection{Direct survey results}

The direct survey conducted in the Italian FV import supply chain allowed us to provide further evidence supporting the research hypotheses formulated.

In the following tables we report interviewees' perceptions of the most important benefits and difficulties related to compliance with food safety regulation and standards. Average Scores (ASs) showed in the tables indicate the relevance attributed by respondents to each item, while Standard Deviations (SDs) calculated shows the consensus across the respondents - the lower the score, the higher the importance attributed to that item; the lower the SD, the higher the consensus.

Table 4 shows that the respondents agree that the overall impacts of compliance with food safety requirements are relevant (total average score $=2.27$ ) and that the most important benefit of compliance is by far the reduction of sanitary risk $(\mathrm{AS}=1.41)$. The interviewees also pointed out that it has important effects on the improvement of market access (2.11), as well as the reduction of commercial risks (2.19). These results confirm our expectations and specifically the first research hypothesis we formulated concerning the effectiveness of EU regulation (H1).

As far as vertical coordination is concerned, respondents emphasize the positive impact on the reinforcement of long-term trust-based relations for firms ( $\mathrm{AS}=2.11)$, while they believe that the EU regulation has limited capacity to increase efficiency in inter-relations among agents $(\mathrm{AS}=2.86)$. These results indirectly only partially support the third research hypothesis formulated, according to which the complexity of vertical relationships along the food chain may affect compliance capacity (H3).

On the other hand, in contrast with the third research hypothesis formulated (H3), respondents agree that relationships among agents do not receive a major benefit from compliance capacity $(\mathrm{AS}=2.86, \mathrm{SD}=1.26)$.

Table 4 - Perceived benefits of compliance with EU safety requirements (1=high relevance - 5=low relevance).

\begin{tabular}{|l|c|c|}
\hline & $\begin{array}{c}\text { Average Score } \\
(\text { AS) }\end{array}$ & $\begin{array}{c}\text { St. Dev. } \\
\text { (SD) }\end{array}$ \\
\hline Reducing sanitary risk & 1.41 & 0.82 \\
\hline Reinforcing long-term trust-based relations & 2.11 & 1.23 \\
\hline Improving market access & 2.11 & 1.13 \\
\hline Reducing commercial risk & 2.19 & 1.11 \\
\hline Improving competitive advantage & 2.32 & 0.87 \\
\hline Improving production and commercial practices & 2.46 & 1.06 \\
\hline Ensuring fair commercial practices & 2.68 & 1.27 \\
\hline Increasing efficiency in inter-relations among agents & 2.86 & 1.26 \\
\hline Total average & 2.27 & - \\
\hline
\end{tabular}

Source: authors' elaboration on direct survey data.

As far as difficulties of compliance are concerned (Table 5), the most critical points is the «scarce harmonization among control systems in $\mathrm{EU} \gg(\mathrm{AS}=1.84, \mathrm{SD}=1.17)$, due to non-homogeneous enforcement capacity in various inspection posts, as well as due to incomplete and/ or delayed information flows (e.g. trade codes not univocally identified, notification of import quotas exceedance), as predicted by $\mathrm{H} 1$. The second difficulty identified relates «insufficient controls on export country borders» $(\mathrm{AS}=1.95$, $\mathrm{AD}=0.98)$, in accordance with the second research hypothesis formulated (H2). An example of this is given by the case of the Citrus Black Spot issued from South Africa that local authorities were not able to stop. The latter issue is of 
particular concern in Italy, where the number of public bodies involved in the inspections is larger than in other Member States.

The third most relevant issue concerns the «scarce harmonization of legislation between EU countries and SMCs» (AS=2.19). In fact, the existence of active substances banned in the EU but authorized in SMCs (and that cannot be always detected by the import inspections) may give rise to potential health risks and unfair competition. This is also the case of exempted uses allowed in certain Member States, such as products containing ethoxyquin (used to preserve pears) or propiconazole (a fungicide for citrus fruits) that are allowed in Spain but not in Italy.

Respondents also report that another critical point relates to "insufficient EU inspections to ensure good practices", along with "difficulties in harmonizing legislation among EU countries", as both items received a score of 2.27.

Again, compliance with EU safety requirements doesn't seem to be a relevant issue with regard to relational issues with local producers in SMCs (since both "access to information" and "contractual relationships" received high AS), entailing that $\mathrm{H} 3$ is not fully supported by the evidence gathered.

Table 5 - Perceived difficulties of compliance with EU safety requirements (1=high relevance - 5=low relevance).

\begin{tabular}{|l|c|c|}
\hline & $\begin{array}{c}\text { Average score } \\
(\text { AS) }\end{array}$ & $\begin{array}{c}\text { St. Dev. } \\
\text { (SD) }\end{array}$ \\
\hline Scarce harmonization among control systems in EU & 1.84 & 1.17 \\
\hline Insufficient controls on export country borders & 1.95 & 0.98 \\
\hline Difficulties in harmonizing legislation between EU countries and SMCs & 2.19 & 1.18 \\
\hline Insufficient EU inspections to ensure good practices & 2.27 & 1.33 \\
\hline Difficulties in harmonizing legislation among EU countries & 2.27 & 1.11 \\
\hline Difficulties in suppliers monitoring & 2.30 & 1.14 \\
\hline Fragmentation of import procedures & 2.30 & 1.14 \\
\hline Difficulties in supplier selection based on good practices & 2.70 & 0.90 \\
\hline Access to information in the countries of origin & 2.86 & 1.44 \\
\hline Difficulties in establishing contractual relations & 3.35 & 1.05 \\
\hline Total average & 2.40 & - \\
\hline
\end{tabular}

Source: authors' own elaboration on direct survey data.

Finally, respondents were asked their opinion on the most appropriate policy action to improve compliance capacity and three main directions have been suggested (Table 6).

First, further inspections in production sites are recommended $(\mathrm{AS}=1.84,1.22)$ along with infrastructure improvement on production sites $(\mathrm{AS}=1.86)$ and "Bilateral cooperation and technical training programs development" $(\mathrm{AS}=1.95)$, to ensure compliance of imported products with health standards, that are consid- ered particularly important in case of perishable products, such as FVs.

Other directions relate to the harmonization of control procedures ( $\mathrm{AS}=1.89$ ), in order to improve regulatory clarity and reduce transaction costs for firms, and the reinforcement of border controls at the country of origin $(\mathrm{AS}=1.97)$ and to strengthen the principle of reciprocity in the European Union's trade with its partners.

Quite interestingly, "Improving compliance with private standards" and "Co-regulation" 
have been judged relatively less important in favoring compliance with food safety legislation, partially in contrast with $\mathrm{H} 4$, but in line with the results of Allani et al. (2016).

Table 6 - Perceived policy needs ( $1=$ high relevance $-5=$ low relevance).

\begin{tabular}{|l|c|c|}
\hline & $\begin{array}{c}\text { Average score } \\
(A S)\end{array}$ & $\begin{array}{c}\text { St. Dev. } \\
\text { (SD) }\end{array}$ \\
\hline Improving inspections on production sites & 1.84 & 1.22 \\
\hline Improving infrastructures in the countries of origin & 1.86 & 1.12 \\
\hline Regulation harmonization between EU countries and SMCs & 1.89 & 1.03 \\
\hline Bilateral cooperation and technical training programs development & 1.95 & 1.09 \\
\hline Reinforcing border controls at the country of origin & 1.97 & 1.01 \\
\hline Improving access to information and knowledge on sanitary norms & 2.05 & 1.33 \\
\hline Simplifying and unifying control procedures & 2.05 & 1.04 \\
\hline Reinforcing border controls at importing countries & 2.41 & 1.22 \\
\hline Technology in production/commercialization in countries of origin & 2.41 & 1.42 \\
\hline Improving compliance with private standards & 2.51 & 1.27 \\
\hline Horizontal coordination among agents in the countries of origin & 2.56 & 1.21 \\
\hline Co-regulation & 2.68 & 1.23 \\
\hline Total average & 2.18 & - \\
\hline
\end{tabular}

Source: authors'own elaboration on direct survey data.

\section{Conclusions}

With the aim to evaluate the impacts of compliance with sanitary standards on the Italian FV import supply chain and to suggest possible improvements in policy action, the study sought for evidence in support of four research hypotheses formulated according to the relevant economic literature. Thus, we collected and analyzed both secondary data - from EU and national public bodies, and primary data - by means of a direct survey on 37 Italian key players.

The first hypothesis (H1), considering the capacity of food safety standard compliance to reduce health risk and commercial risk associated with market failures, was confirmed in the case of FVs imported by the EU and Italy from SMCs both by aggregate secondary data and by the direct survey conducted. Based on the evidence gathered from secondary data sources, we can argue that the current EU food safety regulation and its implementation system is able to pro- vide an appropriate level of protection against the sanitary risk associated with imports of FVs from SMCs. Further, interviewees agree that the benefits of compliance are relevant in terms of reduction of sanitary risk, reduction of commercial risk as well as improvement of competitive advantage for firms.

Yet the empirical evidence provided entails that the there are various critical issues at both legislation and enforcement level that can have negative impacts on domestic firms, confirming the second hypothesis formulated, i.e. compliance with food safety requirements can be improved by effective inspection/control procedures $(\mathrm{H} 2)$. In fact, the main problems arising from compliance with food safety standards are both linked to the complexity of the regulatory framework currently in force and its homogeneous implementation across Member States. Further inefficiencies pointed out by the survey concern non-homogenous border controls, (both inbound and outbound from the country of ori- 
gin), as well as excessive fragmentation of bureaucratic procedures.

As for the third research hypothesis (H3), respondents agree that safety requirements are not a relevant issue with regard to vertical relationships along the supply chain (i.e. difficulties in monitoring/selecting suppliers) and that the current provisioning relationships with producers in SMCs are already satisfactory. However, they think that policy action is needed to pursue greater efficiency in supply chain relationships and they recommend on-site inspections in the countries of origin, along with the strengthening of the reciprocity principle in EU's international trade.

Finally, as far as the relationship between public and private standards is concerned (H4), the study provided contrasting results. In fact, interviewees think that improving compliance with private standards could be important in favoring compliance with food safety legislation. However, they also believe that "Improving compliance with private standards" and that "Co-regulation" are not among the most relevant strategies to be adopted. In the case of Italy, this could be due to the organization of the entry and inspection system, entailing that all the checks are made at the entry points. However, the results of the study suggest that, if the food safety governance could be based on both "obligations of results" and "obligations of means", the potential of a co-regulatory approach between public authorities and firms should be further investigated as an option to enhance supply chain efficiency and exchange relationships between Southern and Northern Countries in the Mediterranean Basin.

\section{References}

Aalders M., Wilthagen T., 1997. Moving beyond command-and-control: Reflexivity in the regulation of occupational safety and health and Environment. Law \& Policy, 19: 415-44.

Ait Hou M., Grazia C., Malorgio G., 2015. Food safety standards and international supply chain organization: A case study of the Moroccan fruit and vegetable exports. Food Control, 55: 190-199.

Allani H., Romdhani A. and Laajimi A., 2016. Adoption de référentiels de sécurité sanitaire dans la fil- ière dattes en Tunisie: Portées et limites pour l'accès aux Marchés d'exportation. New Medit, 15(3): 64-72.

Coutrelis N., 2009. La réglementation communautaire sur les pesticides - la mise en marché des produits phytopharmaceutiques. ERA Forum, Springer-Verlag, 10(2): 231-240.

Crescimanno M., Farruggia D., Galati A., Siggia D., 2013. Intensità degli scambi agroalimentari tra i Paesi del bacino del Mediterraneo. Economia Agro-Alimentare, 1, 13-35.

Emlinger C., Jacquet F., Chevassus Lozza E., 2008. Tariffs and other trade costs: assessing obstacles to Mediterranean countries' access to EU-15 fruit and vegetable markets. European Review of Agricultural Economics, 35(4): 409-438.

European Food Safety Authority, 2015. The 2013 European Union report on pesticide residues in food. EFSA Journal, 13(3).

Fakhfakh F., Grazia C., Hammoudi A. and Merlateau M.P., 2009. Normes sanitaires et phytosanitaires et question de l'accès des pays de l'Afrique de l'Ouest au marché européen: une étude empirique. Document de travail de l'ERMES (Équipe de recherche sur les marchés, l'emploi et la simulation), Université Panthéon-Assas Paris II, Paris.

Fares M., Rouviere E., 2010. The implementation mechanisms of voluntary food safety systems. Food Policy, 3: 412-418.

Garcìa Martinez M., Fearne A., Caswell J.A., Henson S., 2007. Co-regulation as a possible model for food safety governance: Opportunities for publicprivate partnerships. Food Policy, 32: 299-314.

Garcìa Martinez M., Poole N., 2004. The development of private fresh produce safety standards: implications for developing Mediterranean exporting countries. Food Policy, 29: 229-255.

Giraud-Héraud E., Grazia C., Hammoudi A., 2012. Explaining the emergence of Private standards in food supply chains. Cahier Polytechnique 2012-30, Ecole Polytechnique, Département d'Economie, Paris.

Grazia C., Hammoudi A., Hamza O., 2012. The food safety issue: public or private governance? Business and Management Review, 2(1): 102-119.

Grazia C., Hammoudi A., Hamza O., 2012. Sanitary and phytosanitary standards: does consumers' health protection justify developing countries' producers' exclusion. Review of Agricultural and Environmental Studies, 93 (2): 145-170.

Grazia C., Hammoudi A., Hamza O., 2015. Liability rules, inspection systems, and retailers' strategies 
for food import safety. In: Hammoudi A., Grazia C., Surry Y., Traversac J-B. (eds.), Food Safety, Market organization, Trade and development. Heidelberg: Springer.

Hamza O., Hammoudi A., Aliouat B., Grazia C., 2014. Filière et sécurité des aliments: confiance, contrat ou coopération? Revue Économies \& Sociétés, série «Systèmes agroalimentaires», 36: 1589-1614.

Havinga T., 2006. Private regulation of food safety by supermarkets. Law \& policy, 28(4): 515-533.

Helmer O., 1972. Cross-impact gaming. Futures, 4(2): 149-167.

Henson S., Loader R., 2000. Barriers to agricultural exports from developing countries: the role of sanitary and Phytosanitary requirements, World Development, 29(1): 85-102.

Hobbs J.E., 2006. Liability and traceability in agrifood supply chains. In: Ondersteijn C.J.M., Wijnands J.H.M., Huirne R.B.M., van Kooten O. (eds.), Quantifying the Agri-Food Supply Chain. Heidelberg: Springer, 85-100.

Horton L.R., 1998. Food from Developing Countries: steps to improve compliance. Food and Drug Law Journal, 53(1): 139-171.

Laird S., Yeats A., 1990. Trends in non-tariff barriers of developed countries 1966-1986. International Economics Department, World Bank, Policy Research Working Paper, WPS 137.

Malorgio G., Biondi B., Perito M.A., 2016. Strategic behaviour of Italian fruit and vegetables importers from South Mediterranean Countries faced with food safety standards. New Medit, 15(3): 29-36.

Malorgio G., Grazia C., 2013. La performance della filiera ortofrutticola di esportazione dei Paesi Terzi del Mediterraneo nel mercato Europeo: tra concorrenza e cooperazione. Economia Agro-Alimentare, 1: 73-101.

Otsuki T., Wilson J.S., Sewadeh M., 2001. Saving two in a billion: quantifying the trade effect of European food safety standards on African exports. Food Policy, 26(5), 495-514.

Polinsky A.M., Shavell S., 2006. Public Enforcement of Law. Stanford Law School, John M. Olin Program in Law and Economics, Working Paper No. 322, Stanford University, California.

Regulation (EC) No 178/2002 of the European Parliament and of the Council of 28 January 2002 laying down the general principles and requirements of food law, establishing the European Food Safety Authority and laying down procedures in matters of food safety.
Regulation (EC) No 178/2006 of the European Commission of 1 February 2006 amending Regulation (EC) No 396/2005 of the European Parliament and of the Council to establish Annex I listing the food and feed products to which maximum levels for pesticide residues apply.

Regulation (EC) No 396/2005 of the European Parliament and of the Council of 23 February 2005 on maximum residue levels of pesticides in or on food and feed of plant and animal origin and amending Council Directive 91/414/EEC.

Regulation (EC) No 669/2009 of the European Commission of 24 July 2009 implementing Regulation (EC) No 882/2004 of the European Parliament and of the Council as regards the increased level of official controls on imports of certain feed and food of non-animal origin and amending Decision 2006/504/EC.

Regulation (EC) No 852/2004 of the European Parliament and of the Council of 29 April 2004 on the hygiene of foodstuffs.

Regulation (EC) No 882/2004 of the European Parliament and of the Council of 29 April 2004 on official controls performed to ensure the verification of compliance with feed and food law, animal health and animal welfare rules.

Rouvière E., Latouche K. (2014). Impact of liability rules on modes of coordination for food safety in supply chains. European Journal of Law and Economics, 37(1): 111-130.

Starbird S.A., 2005. Moral hazard, inspection policy, and food safety. American Journal of Agricultural Economics, 87(1): 15-27.

Starbird S.A., Amanor-Boadu V., 2007. Contract selectivity, food safety, and traceability. Journal of Agricultural and Food Industrial Organization, 5(1): 1-22.

Vogel D., 1995. Trading up: consumer and environmental regulation in a global economy. Cambridge, MA: Harvard University Press.

Whitakert B., Springer J., Defize P.R., Dekoe W.J., Coker R.D., 1995. Evaluation of sampling plan used in the United States, United Kingdom and the Netherlands to test raw shelled peanuts for aflatoxins. Journal of the AOAC International, 78(4): 1010-1018.

Willems S., Roth E., van Roekel J., 2005. Changing European public and private food safety and quality requirements - Challenges for developing country fresh produce and fish exporters - European buyers'survey. The World Bank, Agricultural and Rural Development Discussion Paper 15, Cost of 
Compliance with SPS Standards. Washington: The World Bank.

Wilson J.S., 2000. The development challenge in trade: sanitary and phytosanitary standards. Paper submitted to WTO Meeting on Sanitary and Phy- tosanitary Standards, June 19th, World Trade Organization, Geneva.

WTO (2015). Sanitary and Phytosanitary Measures - text of the agreement. Available at: https://www. wto.org/english/tratop_e/sps_e/spsagr_e.htm. 